\title{
Finding transformative potential in the cracks? The ambiguities of urban environmental activism in a neoliberal city
}

Dol:

10.1080/14742837.2019.1677224

\section{Document Version}

Accepted author manuscript

Link to publication record in Manchester Research Explorer

Citation for published version (APA):

MacGregor, S. (2019). Finding transformative potential in the cracks? The ambiguities of urban environmental activism in a neoliberal city. Social Movement Studies: Journal of Social, Cultural and Political Protest, 0, [0]. https://doi.org/10.1080/14742837.2019.1677224

Published in:

Social Movement Studies: Journal of Social, Cultural and Political Protest

\section{Citing this paper}

Please note that where the full-text provided on Manchester Research Explorer is the Author Accepted Manuscript or Proof version this may differ from the final Published version. If citing, it is advised that you check and use the publisher's definitive version.

\section{General rights}

Copyright and moral rights for the publications made accessible in the Research Explorer are retained by the authors and/or other copyright owners and it is a condition of accessing publications that users recognise and abide by the legal requirements associated with these rights.

\section{Takedown policy}

If you believe that this document breaches copyright please refer to the University of Manchester's Takedown Procedures [http://man.ac.uk/04Y6Bo] or contact uml.scholarlycommunications@manchester.ac.uk providing relevant details, so we can investigate your claim.

\section{OPEN ACCESS}


Accepted for publication in Social Movement Studies (31-07-19)

\author{
Finding transformative potential in the cracks? \\ The ambiguities of urban environmental activism in a neoliberal city
}

\author{
Sherilyn MacGregor \\ Politics Department and Sustainable Consumption Institute \\ The University of Manchester
}

\begin{abstract}
This article analyzes a unique case of local environmental activism to think through the puzzle of how to interpret the transformative potential of the forms of small scale collective action that have recently emerged in neoliberal cities of the Global North. In response to the call by J.K. Gibson-Graham and others for research that is less driven by abstract theory and more attuned to context and ambivalent possibilities, I present the findings of research co-produced with 'Upping It', a small activist group that uses innovative tactics to clean, green and rehabilitate stigmatized neighbourhoods in Moss Side, Manchester. By enacting forms of interstitial politics, Upping It makes a tangible difference in the lives of ordinary people and creates conditions necessary for politicization, while also participating in unfair and unsustainable local systems. Their story offers rich material for considering the strengths and limitations of two theoretical framings that appear to dominate the literature on micro-political movements: the post-political and new environmentalism framings. These frames, and the criticisms that have been made about them, help to identify two key insights from Upping It that are useful for better capturing the ambiguities and tensions of their kind of struggle in the current conjuncture. These relate to the importance of including justice-oriented activisms, which in this case might be seen as a form of defensive everyday environmentalism, in the emerging picture of new urban movements. Another is the value of finding modest transformative potential in the cracks and on the margins of urban politics.
\end{abstract}

Keywords: everyday activism, environmentalism, post-politics, interstitial politics, transformative change, situated research 


\section{Introduction}

In affluent cities of the Global North, new micro-political movements have emerged that seek to change society through alternative practices rooted in everyday concerns. In this article, I analyze a unique case of local activism in order to grapple with an important puzzle that frames this issue of Social Movement Studies: how should we interpret the capacity of new forms of small scale collective action to effect political change? Are the old tools and framings up to the task or are different approaches needed to fully appreciate the multi-layered and ambiguous character of these movements? These questions have prompted a number of scholars to call for research that is less driven by abstract theory and more attuned to context, unanticipated tensions, and ambivalent possibilities (Gibson-Graham 2006; 2014). A similar motivation shaped research I conducted with Upping It, an activist group that uses innovative tactics such as alley greening to improve local environmental quality. Working in the cracks and at the margins of Manchester, a famous UK site of neoliberal urbanism, Upping It enacts forms of interstitial politics that improve the quality of life of ordinary people and aims towards social empowerment as a necessary precondition for social change. At the same time, it is possible to read into their activism forms of co-optation that pre-empt temptations to fit them neatly into a new 'narrative of hope' (Blühdorn 2017). Thus their story offers rich material for considering the strengths and limitations of dominant theoretical framings of contemporary movements and demonstrates the value of situated interpretation for social movement research.

My analysis contributes to the debate over the transformative potential of new forms of collective action. ${ }^{1}$ This debate goes to the heart of social movement research because it raises key questions of the prospects of change in the face of deeply-rooted structures and of (re)politicization in the face of well-established concerns about the post-political condition. The phrase 'transformative potential' is often used without definition, as if transformation is always and everywhere the uncontested goal of social movement practice. Studies of activism in affluent cities tend to focus on the risks of enrolment into, as well as potential for resistance to, the neoliberal agenda (Uitermark and Nichols 2014; McClintock 2014; Tonkiss 2013). For those who work from within the post-politics theoretical frame, transformation equates to transcending post-politics (Kenis and Mathijs 2014). In research on new environmental activism there is a desire to evaluate how far initiatives succeed or fail in tackling and/or politicizing the root causes of unsustainability (de Moor 2017). Lines in this debate can be drawn between those who tend to idealize small-scale movements because they see in them signs of

\footnotetext{
${ }^{1}$ These debates include the question of whether forms of collective action focussed on everyday life are indeed 'new' or 'movements' at all. There is a reasonable objection that these types of micro-politics have featured throughout the fifty year history of new social movements and have always been central to efforts to politicise the private sphere, such as by feminists.
} 
political resistance and renewal, and those who doubt their radical potential, seeing 'mere coping', cooptation, and more of the post-political same. Critics of the post-political frame reject the argument that the pursuit of alternatives by activist groups should be theorized as depoliticization and have offered examples where alternative practices are both oppositional and part of a consciously anti-capitalist agenda (Asara 2017). Some have called for standing back from this conceptual dichotomy and questioning whether the use of 'hegemonic grammars' built around theoretically-driven readings limits capacity for fine-grained analysis of the 'actually existing struggles' in neoliberal cities (Williams et al 2014: 2798-99).

In the next section, I sketch out the main claims in this debate before identifying problems that are common to both sides. In subsequent sections, I present my case study of Upping It and interpret their activist strategies with reference to key themes in the literature. I conclude with two insights for thinking about and researching with new environmental movements in the current conjuncture. These relate to the importance of including place-based and justice-oriented activisms in the emerging picture of new micro-movements and to the value of finding modest transformative potential by prising open small cracks in urban power structures (Tonkiss 2013).

\section{Theoretical debate: what is the transformative potential of small-scale collective action?}

Research on environmentalism has been gravitating to new forms of activism that are seen to have emerged in affluent societies in recent years. Among the examples most noted in the literature are food justice movements, alternative currencies, energy and housing cooperatives, and Transition Towns. An observed turn to micro-political, place-based alternatives has been explained by post-2008 austerity, by despondency 'after Copenhagen' in 2009 and by the exhaustion caused by several decades of largely ineffectual forms of protest such as mass demonstrations and Climate Camps (Schlosberg 2018; deMoor 2018). ${ }^{2}$ In response to injunctions to reduce carbon emissions, and in pursuit of alternatives to mass consumerism, these initiatives open a new box in the eco-political typology. They bear little resemblance to the radical ecotage of 1980 s deep ecologists and rarely frame their work with demands for recognitional justice as environmental justice activists did in the 1990s and 2000s. The 2010s have seen the rise of small-scale, largely urban and at times experimental initiatives that aim to strengthen social bonds, meet needs by non-market means, and reduce environmental impact. According to those who write about them, these grassroots initiatives or 'new urban practices' offer alternative modes of

\footnotetext{
2 Schlosberg and deMoor have developed this explanation, using 'after Copenhagen' as its short-hand, which they have presented at several conferences attended by this author and which the former elaborates in his forthcoming book Sustainable Materialism: Environmental Movements and the Politics of Everyday Life (Oxford University Press.)
} 
provisioning which simultaneously challenge the capitalist hegemony (Butzlaff and Deflorian 2018). They are increasingly held up as examples to support claims of green political renewal that have been labelled the 'new environmentalism of everyday life' (Meyer and Kersten eds. 2016).

The significance of this turn to the everyday is that, unlike green movements of old, individualist lifestyle strategies are rejected in favour of practices of collectivism and commoning. In an article seeking to advance a unique theoretical approach to understanding these new movements, Schlosberg and Coles see in these examples 'new growths of radical democracy', forms of 'prefigurative politics' and resistance to neoliberal depoliticization (2016, passim). Rejecting a post-political framing, they go so far as to call it 'a new and sustainable materialism' that resists and confronts dominant power structures by 'stepping out of existing flows of material and capital' and transforming 'how human communities meet their basic needs (p. 178). For them, the 'vital and new materialist' theorizing of Jane Bennett and William Connolly provides valuable tools for interpreting the sustainability-oriented strategies and alternative visions of 'food justice movements, new energy collectives and...crafting producers' (Schlosberg and Coles 2016: 177). Commenting on the rise of the 'micro-politics of garden activism', Certoma and Tornaghi (2015) argue that these initiatives need to be recognised for their potential to achieve 'counter-neoliberal urban transformation' (p. 1123). Chatterton similarly characterizes examples urban commoning and co-housing as forms of resistant micro-politics that are part of 'a new movement for post-capitalist transition '(2016: 411). In much the same vein, the radical potential of the Transition Town movement has been found in its stated aims of moving beyond individual behaviour change to 'economic renaissance' and 'relocalization' on the path to a post-carbon society (North 2010). For scholars inclined to see the promise in these movements, such eco-political developments prompt new theoretical questions and offer reasons to be hopeful that a more sustainable reconfiguration of sociomaterial and capitalist relations is underway.

For another set of scholars, however, the instinct is to be sceptical of these celebratory declarations. It is not that they question claims to 'new-ness' (though they should), but rather to suggest it is too soon to tell if these prefigurative practices will bring about structural and environmental change because many 'lack the political-strategic arm' found in most social movements (Butzlaff and Deflorian 2018). Theorists viewing these movements through the lens of post-politics suggest that they represent little more than performative coping strategies without much believable potential for being transformative. The Transition movement has been subject to particularly crushing critiques for being exclusionary, inherently apolitical and for 'merely "coping" or tinkering where more radical forms of change are required' (Brown et al. 2012: 1608). For example, Kenis and Mathijs (2014) are critical of those who celebrate the potential of the Transition movement because they underestimate the 
complexity of the problem of post-politics. They draw on the work of Marxist geographer Erik Swyngedouw (2013) to hypothesize that many alternative forms of green activism have emerged in the context of post-politics. This theoretical framing is adopted by many who want to see signs of resistance, radicalism and subversion of neoliberal consensus before they are willing to accept that examples of collective action are truly getting beyond post-politics.

Blühdorn (2017) draws on his theory of post-ecologism to question the validity of interpreting new eco-political developments as signs of hope that radical transformation is on the horizon. ${ }^{3}$ Taking issue with the work of Schlosberg and Coles, and others who are 'raising expectations about a "renewal of environmentalism"', he suggests that their optimism is made possible by denial of contemporary forms of anti-politics and the enduring nature of capitalism (p. 53). He argues that these new activisms are better seen in the light of the fundamental culture shifts that have occurred in neoliberal consumer democracies whereby the desire for material accumulation and lifestyle choice is stronger and nonnegotiable than normative beliefs in preserving 'nature' or achieving democratic self-determination. There may still be eco-political movements and activists, but they operate, he contends, within a space of inescapable unsustainability where only management, coping, and simulation are possible. What is more, to the extent that forms of consumption, such as buying local foods or ethical clothing or green energy, are used to counter the negative effects of capitalism, contemporary environmentalism continues to sustain what it seeks to challenge.

Each of these positions in the debate offer useful critical tools for making sense of what may or may not be a new chapter in the environmental movement story. Their strengths lie, respectively, in offering new theoretical interpretations of small-scale urban movements and offering more established critique of neoliberalization in which to view and critically analyze the potential of these movements. These are of course different and equally useful aims. Yet both have similar limitations that have been identified by critics. The post-politics literature seems to have the most self-identified discontents, possibly because it has been around longer and because its pessimistic and theoretically-driven evaluations of social movement struggles tend to put these discontents on the defensive (Loftus 2014). Aiken makes the point that 'a post-political diagnosis can conceal as much as it reveals' (2017:2396). ${ }^{4}$

\footnotetext{
${ }^{3}$ Blühdorn's post-ecologist condition should not be conflated with the wider scholarship on postpolitics. There are some surface similarities but also important differences at a fundamental level. For the purposes of my discussion, the relevant similarity is his theoretical critique of hegemonic neoliberalism and consumer capitalism that leads to scepticism about 'new, hopeful' forms of everyday or 'lifestyle' environmental politics.

${ }^{4}$ An important line of critique is the tendency in this literature to reify and present neoliberalism and the neoliberal city as fixed, monolithic objects.
} 
This statement may also apply to the new-environmentalism diagnosis presented by Schlosberg and Coles (2016) among others. On my reading, there are two problems with the way these positions approach their task.

First, both engage in a mode of 'strong theorizing' that tends to downplay empirical ambiguities. Gibson-Graham defines strong theory as 'powerful discourses that organize events into understandable and seemingly predictable trajectories' (2014:S148). Both post-political and new environmentalism theorists base their evaluation of transformative potential on the extent to which neoliberal consumer capitalism is threatened by alternative practices. Arguably this amounts to a 'capitalocentrism' that reads for domination rather than begin open to difference (Gibson-Graham 2006). We might also say that the conceptualizations of the political and ecologism that are invoked in this work are based on particular readings of social theory where politics is only about conflict and confrontation (Wilson and Swyngedouw 2014) and ecologism is a specific movement with a radical critique/vision of socioenvironmental relations underpinned by abstract Enlightenment ideals (Blühdorn 2017). Both seem to display what McNay has described as 'an abstract way of thinking about the world that is so far removed from the actual practices and dynamics of everyday life' that one can question is relevance for analyzing social movements (2014: 4). While not wishing to suggest a reduced role for theory in social movement research, I argue that - at least in the debate at hand - the tendency to put theory in the driver's seat limits the capacity to illuminate the interesting ambiguities to be found in the diverse strategies that are emerging in response to environmental problems under conditions of austerity and neoliberal policy making.

Second, there appears to be either a lack of empirical examples or a tendency towards selection of examples that serves the theoretical purpose of those commenting on these ostensibly new forms of activism. This is not a new observation to make: critical feminist geographers have long expressed concern that strong theory sets the intellectual agenda but offers only thin or highly selective descriptions of real world cases. By avoiding the challenges of in-depth, ethnographic research scholars can slide around their theories to avoid criticism (Katz 1992). In many respects post-political and 'sustainable materialism' approaches may be travelling down this well-trodden path. It is significant that on both sides of the debate there tends to be minimal description of empirical examples of the new movements at the heart of their contributions. For example, Schlosberg and Coles (2016) want to build a new category of social movement on a handful of examples from three cities with very few details about participants or impacts. Blühdorn (2007) on the other hand makes no apologies for his lack of empirical evidence, pointing to the important role of meta-theory in developing diagnoses of sociological phenomena. Both appear to make claims that lack 'academic attentiveness' to local context and 
specificity (May and Cloke 2013). So, following a number of critical scholars, I suggest that a weak and situated approach to interpreting new forms of everyday activism is preferable over the strong and slippery approach that arguably seems to be popular in recent scholarly literature.

Larner (2014) uses this kind of situated approach to researching Coexist, a radical social enterprise in Bristol, which enables her to interrogate the strengths and limits of the post-political theoretical frame. She does so because she worries that the debate about post-politicization can seem ignorant of 'the actual initiatives, ideas and techniques involved' in activist practices, and leads as a result to 'relentless pessimism' (2014:190-191). Her response is to call for looking closely at empirical cases and resisting the urge to 'too quickly foreclose the politics and potential' of these initiatives ( $p$. 203). At the same time, Larner is careful not to paint an over-hopeful portrait of Coexist by identifying aspects of the organization's work that appear to support rather than resist neoliberalization of the third sector in the UK. What is most instructive for my project is her suggestion that 'by making the content and form of contemporary political struggles more visible, it might be possible to overcome our [postpolitical] cynicism about the impossibility of politics in the current conjuncture' (p. 204).

There are several other scholars whose situated research yields useful tools for thinking about the question of transformative potential. In their work the term 'interstitial politics' has been used to theorize conceptual in-between-ness as well as to capture the kind of activity that occurs on the margins of neoliberal capitalism, austerity urbanism and other dominant power structures. For example, Williams et al. follow Gibson-Graham's lead in taking a weak theoretical stance - 'reading for difference rather than domination' - in order to render visible forms of social agency and resistance that occur within the spaces of neoliberal governance and 'in the meantime' (2014: 2798-9). They suggest that studying the 'interstitial politics of resistance and experimentation' (p. 2798) found in local activist examples is a welcome alternative to a wishful reliance 'on some messianic rupture in the political '( $p$. 2811) commonly found in Marxist literature. They stand with Erik Olin Wright (2010) in wanting 'a bolder vision of political activism as a series of interstitial political sensibilities and practices that work strategically, even subversively, with tools that are at hand' (Williams et al 2014: 2811). In a similar vein, and with a clear explanation of what is meant by 'cracks' in this literature, Tonkiss uses the words 'interstitial' and 'provisional' to describe activist experiments that 'work both under and against current economic and political constraints; which take chances when they can be made to present themselves' (2013:323). She writes they can be both 'seed-beds' of transformation and have potential for 'selling out' by fostering gentrification or by taking on unpaid work that has been downloaded to citizens by a neoliberal state. According to Keil (2013), this ambivalent potential to be simultaneously coping, contestatory and co-opted is par for the course for most urban environmental movements in the 
context of 'roll-with-it neoliberalism'. This is why many scholars argue for an approach that allows for both-and interpretations, rather than attempting to judge whether a particular urban movement or collective practice is 'properly' political. For them it is more accurate to treat small-scale actions as necessary steps to making slow political change over time (Wright 2010). ${ }^{5}$

Interstitial political practices that focus on everyday concerns in urban places, such as neighbourhood- level environmental quality, are under-researched in environmental politics and, arguably, in social movement studies. Researching such activisms in a collaborative and ethnographic way is even less common according to Lozano (2018), which is how my research with Upping It contributes to both fields.

\section{Upping It in Moss Side: research with neighbourhood environmental activists}

Manchester has long provided a rich context for studying the interlinked processes of globalization, neoliberalization, regeneration and exclusion (Peck and Ward 2002). Moss Side is an inner city Manchester ward with serious social and environmental problems and reputational stigmatization over several decades. It is one of the most deprived and racialized areas of England and a national symbol of gang-related crime. Although it has a multicultural population, for the past 50 years it has been known as a 'black space' due to its role as a gateway for people-of-colour migration (Brown and Cunningham 2016). It is in an area with one of the lowest voter turn-outs in the country (Booth 2015) and has suffered from a decade of austerity in the UK (Etherington and Jones 2017). Its geographical proximity to two large universities and a sustained period of low interest rates have resulted in a dramatic increase in student rental properties in the past decade. It is this 'studentification', along with transience and deprivation, which are commonly used to explain the poor state of the street environment. In particular, there is a serious problem of litter, the lowest recycling rate in the city, and degraded public spaces that local residents describe with the words 'squalor' and 'third world conditions' (MacGregor and Pardoe 2018). Despite increased precarity and enduring stigma in Moss Side, however, there is a small core of residents who take part in community organizing. These groups have no free, public place to meet, very little online presence, and are known largely by word-of-mouth via local networks. I became aware of the group called 'Upping It' by a chance encounter with a founder-member in the street. It was from her that I learned that the organization has been pursuing a range of strategies for cleaning up the local environment since 2013. Our conversation led to an invitation to a meeting and then, over time, to a collaborative research project.

\footnotetext{
${ }^{5}$ There appears to be a slow temporality in these types of activism that would be interesting to explore in future research.
} 


\section{Research methods}

Several scholars call for a situated approach to researching social movements (Gillan and Pickerill 2012; Pink 2012). For example, informed by recent work in Southern urbanism, in which there is a call to resist homogenizing tendencies of Eurocentric Marxist scholarship, Lawhon et al argue that a situated approach will yield 'a broader range of urban experiences to inform how urban environments are shaped, politicized and contested' (2014: 498). Such an approach starts from specificities of a place and endeavours to describe before explaining. This practice is demonstrated in the work of Sarah Pink (2012) who, as a feminist theorist, is especially attuned to the ways in which activism that emerges out of everyday concerns can be trivialized as not-real-politics and so needs to be approached with openness to their unexpected significance. She suggests that the key to meeting this challenge is to be reflexive about the relationship between research frames and activist practices, an approach that is compatible with a political commitment to working with activists to co-produce socially useful research. It connects to what Lozano has recently identified as a 'collaborative turn' in social movement studies, which might be an antidote to the tendency within the field to impose its own debates while 'show[ing] little interest in engaging in dialogue and joint explorations with ...activists' (2018:456).

Consistent with this turn, my research was conceived and planned collaboratively. Over several meetings, I worked with members of Upping It to identify research questions. Our agreement was that we would work together to research their questions (mostly relating to the local rubbish problem and what more could be done to address it) while I was researching them. This can be described as an 'immediately reciprocal' relationship (Gillan and Pickerill 2012) that was strengthened by the fact I have a long term commitment to the neighbourhood (i.e., I live there). Taking the role of project leader (which involved getting funding to pay for their time and a new website), allowed me to develop a trust relationship with potential for long term engagement. My research with Upping It lasted about one year, during which time I interviewed the most active members, attended their steering group meetings, and facilitated a focus group discussion. I was given access to the group's email correspondence about local issues and actions. Members of the group worked with me to conduct a funded research project in their neighbourhood. ${ }^{6}$ Interviews were transcribed and analysed alongside field notes and photographs were taken during my bi-weekly walks around the streets and alleys in the neighbourhood. To ensure reliability and validity, I interviewed 15 elite professionals working with waste, housing and student issues in the area (including Manchester City Council [MCC]) with whom Upping It has had contact over

\footnotetext{
${ }^{6}$ Space constraints do not allow for a discussion of this co-produced research. Details can be found on the Upping It website.
} 
the past five years. I also offered up my preliminary draft of the findings and held feedback conversations with participants.

\section{Interpreting Upping It: analysis and reflections}

I have no doubt that increasing numbers of debt-fuelled students are making institutions like the University of Manchester richer. But I don't feel richer... Exactly the opposite. I don't want to be told about the 'benefits' of increased student numbers, I want to have my grievances acknowledged and for something to be done about salvaging and/or protecting my neighbourhood. I have a simple and very clear demand: I want a decent quality of life where I live. [...] My hedges free of vomit. My pavements free of broken glass. A place where I know my neighbours and can indulge in the placid enjoyment of my local area without being affronted by 'TO LET' signs ... or drowning in a sea of unmanaged waste... (Upping It activist, email 2018)

This quotation is an effective introduction to my analysis of Upping It's activism because it affords an uncomfortable glimpse into the context in which they work. Unlike many of the everyday movements and activist initiatives profiled in the contemporary eco-political literature, Upping It came together as a response to the local impacts of austerity and to challenge the effects of harmful yet normalized consumption practices on a stigmatized neighbourhood. They are not pursuing alternative forms of provisioning beyond the market, but cleaning up the mess. Members call themselves 'activists' and describe their strategy as community-based action to defend and improve life for Moss Side residents. Stemming from a shared local analysis of the problem, Upping It members employ a range of tactics to try to achieve their long term aims. Here I discuss direct intervention in local waste systems, alley greening, and community building. Effects of each of these tactics are interpreted in relation to themes and concepts in the literature set out earlier.

\section{Practical effects: direct intervention in local waste systems}

Swingeing cuts to MCC's budget starting in 2010 not only put local services at risk, but the quality of the street environment was being left to degrade to intolerably low levels. Recognizing that the cuts were sucking funds out of the area, a group of residents decided that something could be done locally by reducing the cost of waste collection. The group's reasoning was that if they could 'up' the level of recycling in the area (hence the name 'Upping $\left(t^{\prime}\right.$ ), the cost of sending residual waste to landfill could go down and more money could be directed back to the community. Although this reasoning was soon refuted, Upping It's strategy of direct intervention to improve local waste practices remains the foundation of their work.

Much of Upping It's activism involves raising consciousness and increasing resident compliance with the local waste system. Because most people living in the area are transient, the group works to 
disseminate information about how to manage household waste, including where to put it, how to separate it, when to put it out for collection and how to report problems. A network of Upping It street reps send texts to remind neighbours of correct waste and recycling practices, while core steering group members deliver hand-decorated food waste bins and charity donation sacks to student tenants with a personal encouragement to adopt good waste habits. I observed members of Upping It doing the rounds on the mornings after 'bin night' to help return bins to the right place and personally deliver 200 British Heart Foundation donation sacks to student houses, work that the universities claim to do themselves and for which they have earned social responsibility awards ( $U$ of $M$ press release, July 2018). These interventions involve Upping It replacing or topping up with volunteer labour the services that were once delivered by paid workers.

These last two observations indicate that Upping It is having a direct and practical effect on local waste problem by performing work that local institutions are failing to perform. While valuing the benefits of these tactics, it is also possible to see them as a form of co-optation. This reading would resonate with familiar arguments about the instrumentalization of civil society and the responsibilization of individuals that are well rehearsed in post-politics critiques of neoliberalism (Larner 2014). In this case, the activists openly accept the state's downloading of responsibility for local environmental quality onto volunteers. They appear to accept (if not embrace) the idea that voluntary groups should take an active role in tackling neighbourhood waste problems. This idea is promoted in the 2017 Litter Strategy for England, a central government policy that calls on community groups to clean up rubbish while saying almost nothing about the role of corporate producers of rubbish (MacGregor 2017). It is a depoliticization of the waste problem that is ripe for placing in the context of neoliberal governance and yet it plays no role in Upping It's outlook. In fact, during my focus group discussion of the Litter Strategy, I suggested they could not only withdraw their support for recycling but also organize a 'recycling strike' to politicize the issue locally while costing the Council money. Members were vehemently opposed to this suggestion because, even though withholding their unpaid labour from the waste regime might hurt MCC, it would hurt local people even more: they would once again be surrounded by litter fuelling stigmatization and further distress. Of two evils, a DIY strategy is better than 'drowning in a sea of unmanaged waste'. My 'more political' strategy (as I called it) was simply not an option. Recognizing this point problematizes the tendency in post-political theorizing to valorize radical resistance tactics without recognizing that these high cost-high risk moves often are not possible for people living with the daily effects of austerity and eco-spatial injustice.

\section{Alley greening: transforming place}

Upping It's most innovative tactic has been alley greening, whereby they organize groups of residents to 
work together to clean up and then to green the shared alleys behind their houses by installing raised beds and planting flowers and edible plants for communal enjoyment. Including pollinator-friendly plants is a particular interest, and so is reducing food waste available for rats and pigeons. In addition to creating relationships between people who live there, alley greening is intended to stop the high rates of fly-tipping by people who don't. Since 2013 the group has been responsible for greening over 35 alleys, with more in progress. The physical transformation in some parts of Moss Side is impressive.

As with the first point, there are aspects of this tactic that should be of interest to both sides in the transformative potential debate. On the one hand, the alley greening work resonates with Schlosberg and Coles' 'sustainable materialism', which they explain as a movement for politicizing the connections between human needs and 'the flows of the non-human realm' (2016:161). By filling the alleys with plants and enrolling neighbours in the project of tending them together, Upping It's activism brings Moss Side residents into contact with the needs of other people and with the cycles of nonhuman living things. In the past, Upping It members have used arguments about rats, flies and smell to convince people to change their food waste practices, but more recently have found that promoting bee-friendly plants and showing the value of composting leads to greater buy-in. Using the compost made by the Council for their alley planters closes a loop. As one member explains, 'They say, "Soil for planters comes from our waste? But how?" So we show them how and I think doing this really helps people to understand the point of composting; most people are so uninitiated into how nature works'.

The alley greening tactic could also be read as an example of 'urban commoning' that has been celebrated as a new urban practice for connecting people with each other as well as the natural environment (Chatterton 2016). Theorizing the commons has become an emerging theme in the study of eco-social transformation. The new commons movement has developed in recent years as a direct critique of neoliberal capitalism and the enclosure of public spaces (Bradley 2015). It seeks creative, selforganized systems for meeting needs through a parallel economy beyond the market. Acts of commoning, such as squatting in empty buildings, occupying private land, and guerrilla gardening, aim to 'subvert both the exclusions of private property and the prescriptions of the state' (Tonkiss 2013:322). The most commonly studied form is community gardening, but in places like Moss Side where there is no space for gardens, and very little green space to speak of, alley greening is an interesting innovation. In fact, given its situation in a deprived urban neighbourhood, Upping It's alley greening could be read as an example of what Tonkiss calls as a 'makeshift', interstitial political strategy: it is literally and figuratively an attempt 'to prise open the cracks in the hard surface of austerity urbanism' (Tonkiss 2013:317). Upping It members describe their alley greening as a way, not only to 
resist degradation and dumping, but also to care for a neighbourhood that is hurt by stigmatization, insecurity and the shrinking of the local state.

Yet it is important to curb enthusiasm by recognizing aspects of alley greening that achieve outcomes that are less than transformative of the post-political status quo. For one thing, some will wonder whether it might be a form of 'green gentrification', a term sometimes used by those who are sceptical of the inclusive nature of urban greening practices such as community gardening. As Anguelovski (2016) observes, many celebrated cases of neighbourhood transformation through ecological improvement occur at the expense of racial and social equity. She cites examples of US environmental justice (EJ) activist groups who are fighting green gentrification because it leads to the displacement of poor and racialized communities by middle class home-owners. What makes the Upping It case an interesting addition to this research is that they are using a greening strategy to fight the deleterious effects of studentification, which is not the same as gentrification. Moss Side may be an attractive place for middle class investors, but these are absentee landlords who buy houses at reduced rates from elderly Caribbeans, renovate them to add rooms and then rent them to students for profit. The area is increasingly becoming crowded, messy and inhospitable for non-student residents regardless of economic status. So rather than worry about the risk of green alleys making the neighbourhood susceptible to take-over by elite white people, it is perhaps more accurate to see Upping It's tactic as a form of defensive environmentalism. That there are few positive labels for this kind of defensive activism should prompt further critical reflection. This can be explained, according to Anguelovski (2016), by the fact that excitement over small scale greening projects in cities has tended to close off research into the tensions EJ activists experience when fighting for environmental improvements in poor areas of rich cities.

Perhaps more relevant to my case, therefore, is the practical problem that the alleys are very difficult to keep clean and green, so only the most privileged among Moss Side residents are able to maintain them regularly. Some people are too elderly to care for plants and others are too poor to use their own metered water supply to tend plants in summer. The incidence of failure is high and the disillusionment caused when alleys fail potentially does more harm than good. The sight of a greened alley that has been left to decay and return to a dumping ground can affirm the negative of Moss Side's dysfunctionality. Worse, it can lead to a sense of defeat that undermines potential for sustained activism. The frustration expressed by Upping It activists over failed alleys was heart-breaking to observe but also highlights, as a growing number of urban scholars are doing, the importance of gathering stories of failure to militate against the temptation to romanticize activist experiments (Harrowell et al. 2018). 
Transforming relationships: building solidarity, demanding respect

Upping It members spend most of their activist time engaging in the mundane practices of picking up litter and managing other people's rubbish. They do so with the larger aim of creating the conditions for neighbourhood solidarity and a collective commitment to a better quality of life in Moss Side. Among their tactics for building solidarity are organizing community feasts and creating a network of active street reps. Alley greening also offers potential to transform social relationships. As one activist commented:

...this [alley] project has helped to break this alienation and this has been the biggest inducement to get involved of all: the community coming together, collaborating, getting to know each other, having a sense of place and security - all of which they didn't have before.

The group's long term strategy is to build enough 'social capital' (their words) to be able rehabilitate Moss Side's reputation and to exert sustained pressure on MCC and the universities to join residents in defending the area from further decline. In this sense their strategy serves to politicize the problem so that residents might resist blame. Current MCC environment and waste policy sends a clear message that rubbish in the streets can best be tackled by educating residents, nudging them to recycle more and encouraging voluntary neighbourhood litter picking. As per the standard feature of neoliberal policy, a deficit view of the public trumps acknowledgment of structural causes. While Upping It may participate in this agenda to some extent, they also take every opportunity to challenge it by pointing out flaws in the system and putting forth an analysis of the interconnections of lack of respect for poor, racialized people by the local state and the political economy of studentification. The criticisms of the rubbish problem is underpinned by a belief in eco-spatial justice, which holds that all citizens should have fair and equal access to liveable spaces and places regardless of whom they are or where they live in the city.

On the other hand, Upping It's advocacy for Moss Side does not come without potential drawbacks. There is always the possibility of being seen as a negative form of 'unreflexive localism' where 'solidarity risks being restricted to people from nearby, maybe even to people "we know"' (Kenis and Mathijs 2014:178). Such parochialism may blunt the political edge of their strategy, especially if it is accompanied by hostility to particular outsiders such as students. Interviews indicated that students are generally welcomed but also tend to be painted with the same brush, as being 'too cool to care' and 'snobby' about the area, which may well reaffirm rather than transform negative town and gown relations. It is also possible that efforts to prevent fly-tipping in Moss Side alleys could simply displace the problem to other poor parts of the city, thus undermining a sense of solidary among a significant segment of Manchester's already-fragmented and disenfranchised population (Booth 2015). A final 
drawback is that their focus on cleaning up and upping recycling rates is not accompanied by a campaign for reducing waste at its source, as in or lobbying for 'zero-waste' approach and the banning of single use plastic. They participate in what Blühdorn calls 'sustaining the unsustainable'. As a result, efforts to boost local empowerment and solidarity sit next to largely uncritical acceptance of consumer-capitalist relationships with the stuff that becomes the waste that degrades their environment.

These interpretations of Upping It's activist story suggest that it is a complex example of urban environmental activism that resonates with a range of questions scholars are asking about the kinds of political action that are emerging after many years of austerity policies in rich cities. What my interpretations have demonstrated is that while each would find aspects to confirm their theoretical suspicious, neither of the two positions in the debate mapped out in the first part of this discussion on its own is sensitive to the full range of ambiguities and tensions that characterise Upping It's experience. By taking a weak and situated approach to interpreting the effects of their work, I have been able to draw out and reflect upon the challenges of doing neighbourhood-level environmental activism under conditions that few theorists involved in the transformative potential debate may have had occasion to contemplate.

\section{Conclusion}

This article has explored the challenge of interpreting a unique case of environmental activism in light of questions surrounding the transformative potential of small-scale activism beyond post-politics. My discussion of Upping It is situated within a debate over whether everyday forms of activist practice represent a new form of environmentalism or just a new phase in its enrolment into the post-political (neoliberal, consumer capitalist) status quo. I considered the claims mobilized by two positions in this debate and drew on critical literature to identify some of the limitations of theory-driven framings. I aligned myself with critics who eschew 'strong theory and thin description' (Gibson-Graham 2014) in favour of looking for modest signs of transformative potential in interstitial and incremental politics through a more situated, placed-based approach. I then used this approach to make sense of the efforts of a group of activists with whom I conducted research. From this analysis I have developed insights into what the case of Upping It can tell us both about everyday struggles for social and environmental change in a neoliberal city as well as the direction that theorizing such initiatives should take.

First, the reason I was compelled to do research about/with Upping It is that they are not the usual suspects, not the typical kind of activists who appear in dominant narratives of eco-political activism. In many ways, trying to interpret their case using the frames at hand was like trying to fit a square peg into a round hole. Doing so has led to critical reflections on the shape of the hole itself. 
Upping It members do not resemble the switched-on hipsters who engage in 'new urban practices' (DeFlorian 2017; Schlosberg and Coles 2016) as part of a self-conscious choice to reduce their impact by changing their relationship to stuff. Neither would it be accurate to give them the label 'lifestyle politics' because that would unfairly reduce their efforts to a self-interested pursuit of an acceptable green identity within a consumer capitalist society (Blühdorn 2017). And nor do they fit into the box labelled post-capitalist/post-carbon Transition (Chatterton 2016). They are not consuming their way to sustainability nor actively seeking the rupture of the capitalist system, but they do seek social, political and environmental justice for Moss Side 'in the meantime' (Williams et al. 2014:2799). This insight raises the question of whether the debate over the transformative potential of new environmentalisms focusses on abstract questions about 'the political' to the neglect of situated questions of everyday justice. Whereas the environmental justice movement has long questioned the relegation of poor, racialized and feminized bodies to the margins of eco-politics, the contemporary trend is to celebrate exceptional cases of small-scale urban activism and to judge them through the lens of strong theory. That groups like Upping It are difficult to fit into neat framings reminds us that these frames are imperfect tools even while they do help to discern the potentials, dangers and contradictory tendencies in the empirical cases we study.

Second, I have argued that Upping It's strategies are best seen as forms of interstitial politics that aim to prise open in the cracks of political life of a city hardened by ten years of neoliberal policy. This is not a new way of thinking about political activism; indeed it seems well explored in the literature on austerity urbanism (Tonkiss 2013). But interstitial strategies are often rejected by researchers located in Marxist-inspired traditions because they are not counter-hegemonic enough - 'they [as seen to] deflect energies from the real political challenge of changing the world for the better' - as Wright observes (2010:326 emphasis added). This logic is apparent in the literature on post-politics. But Wright goes on to argue for the role that interstitial strategies can play in emancipatory social transformation over the long term. Insofar as it improves quality of life and builds social connections for ordinary people in capitalism, acting interstitially should be valued as part of the political project of imagining that another world is possible. Whether such a project necessarily requires a turn back to 'strong theory' is a question for debate. Following this more optimistic reading, and in light of my experience with Upping It, the central argument for this paper is that the concept of 'interstitial politics' is a way of understanding the efforts of actually existing urban struggles that should be embraced by scholars of everyday environmentalism. 'Interstitial environmental activism' may be superior to phrases with 'lifestyle' or 'everyday life' in them because it signals the interventionist and strategic nature of the activism and avoids the (negative) individualizing connotations that most mainstream political theorists associate 
with politics of the mundane, rooted in the private sphere. At the same time, it is important to resist the conflation of lifestyle and everyday, and perhaps to reclaim the latter's political significance as well as its potential for extending ideas of environmental justice to a different register that includes defending people and place against undesired changes.

Allowing the strong-theoretical 'posts' (i.e., post-politics, post-ecologism, post-growth, postcapitalism) to drive the interpretive train seems to have set many scholars on routes toward naïve optimism or paralyzing pessimism. These are the destinations that Gibson-Graham (2014) seek to bypass by approaching diverse examples of alternative political practice through weak theory and situated description. They may take shortcuts that some scholars will resist, but the important point is to be more open to what 'small facts say about big issues' rather than (or at least in addition to) the other way around (Gibson-Graham 2014). Although my year-long, grounded analysis of Upping It admittedly does not yield definite answers about its future potential, it seems that the impact they have made locally is not just prefiguring a better society but declaring that the residents of Moss Side are as deserving of one as everyone else. It is by reflecting on the ambiguities and tensions found in this kind of work that we might develop better tools for understanding the significant political difference small scale collective actions can make.

\section{Acknowledgements}

The research project was funded by the Higher Education Innovation Fund (Research England), with additional financial support from the Sustainable Consumption Institute at the University of Manchester. Thanks are due to Simon Pardoe and other members of Upping It who collaborated on the research design, data collection, and interpretation and dissemination of the project results. Thanks also to Ingolfur Blühdorn, Michael DeFlorian, Luke Yates and the anonymous peer reviewers for their detailed feedback on the manuscript. I accept responsibility for any remaining errors.

\section{References}

Aiken, G. T. (2017) 'The politics of community: Togetherness, transition and post-politics. Environment and Planning A 49(10): 2383-2401.

Anguelovski, I. (2016) 'From toxic sites to parks as (green) LULUs? New challenges of inequality, privilege, gentrification, and exclusion for urban environmental justice' Journal of Planning Literature 31(1):23-36.

Asara, V. (2017) 'Social movements and resistance', in Spash, C. (ed.) The Routledge Handbook of Ecological Economics. Abingdon: Routledge, pp. 73-182.

Blühdorn, I. (2017) 'Post-capitalism, post-growth, post-consumerism? Eco-political hopes beyond sustainability' Global Discourse 7(1):42-61, 2017.

Blühdorn, I. (2007) 'Self-description, self-deception, simulation: A systems-theoretical perspective on contemporary discourses of radical change' Social Movement Studies 6(1):1-19. 
Booth, R. (2015) 'Apathy central: the place with the lowest voter turnout in Britain. The Guardian 16 April, online at: https://www.theguardian.com/politics/2015/apr/16/political-engagement-voterapathy-registration-manchester-westmorland-lonsdale (accessed 15-09-17).

Bradley, K. (2015) 'Open-source urbanism: Creating, multiplying and managing urban commons' Footprint: Delft Architecture Theory Journal, 16 (Spring): 91-108.

Brown G., Kraftl P. and Pickerill J. (2012) 'Holding the future together: Towards a theorisation of the spaces and times of transition'. Environment and Planning A 44: 1607-1623.

Brown, L. and Cunningham, N. (2016) 'The inner geographies of a migrant gateway: Mapping the built environment and the dynamics of Caribbean mobility in Manchester, 1951-2011' Social Science History 40(1): 93-120.

Butzlaff, F. and Deflorian, M. (2018) 'The shifting nature of prefiguration in social movements: From modelling to expressing alternatives? ISA World Congress of Sociology, Toronto, July 2018.

Certoma, C. and Tornaghi, C. (2015) 'Political gardening: transforming cities and political agency' Local Environment 10: 1123-1131.

Chatterton, P. (2016) 'Building transitions to post-capitalist urban commons' Transactions of the Institute of British Geographers 41: 403-415.

Deflorian, M. (2017) 'Community gardens and repair cafés as political counter-movements? Assessing new urban practices from the perspective of new social movement theory'. ECPR annual conference, Oslo, September 2017.

Etherington, D. and Jones, M. (2017) 'Devolution, austerity and inclusive growth in Greater Manchester'. Online at: https://www.mdx.ac.uk/ data/assets/pdf file/0030/368373/Greater-ManchesterReport.pdf?bustCache $=92145287$

Gibson-Graham, J-K. (2006) A Postcapitalist Politics. Minneapolis: University of Minnesota Press.

Gibson-Graham, J-K. (2014) 'Rethinking the economy with thick description and weak theory' Current Anthropology 55(S9):147-153.

Gillan, K. and Pickerill, J. (2012) 'The difficult and hopeful ethics of research on, and with, social movements' Social Movement Studies 11(2):133-143.

Harrowell, E., Davies, T. and Disney, T. (2018) 'Making space for failure in geographic research' The Professional Geographer 70 (2):230-238.

Katz, C. (1992) 'All the world is staged: intellectuals and the projects of ethnography' Environment and Planning D; Society and Space 10, 495-510.

Keil, R. (2009) 'The urban politics of roll-with-it-neoliberalism' City 13(2):230-245.

Kenis, A. and Mathijs, E. (2014) '(De)politicising the local: The case of the Transition Towns movement in Flanders' Journal of Rural Studies 34: 172-183.

Larner, W. (2014) 'The limits of post-politics: rethinking radical social enterprise' in J. Wilson and E. Swyngedouw (eds.) The Post-political and its Discontents, pp. 189-207. Edinburgh University Press. 
Lawhon, M., Ernstson, H. and Silver, J. (2014) 'Provincializing urban political ecology: Towards a situated UPE through African urbanism.' Antipode 46(2):497-516.

Loftus, A. (2014) 'Against speculative leftism' in J. Wilson and E. Swyngedouw (eds.) The Post-political and its Discontents pp. 229-243. Edinburgh University Press.

Lozano, A. Arribas (2018) 'Knowledge co-production with social movement networks: Redefining grassroots politics, rethinking research' Social Movement Studies 17(4):451-463.

MacGregor, S. (2017) 'Why England's litter strategy is actually a bit rubbish' The Conversation, September 15. Online: https://theconversation.com/why-englands-new-litter-strategy-is-actually-a-bitrubbish-81202

MacGregor, S. and Pardoe, S. (2018) 'Talking Rubbish in Moss Side'. Report available at: www.uppingit.org.uk.

May, J. and Cloke, P. (2013) 'Modes of attentiveness: reading for difference in geographies of homelessness' Antipode 46:894-920.

McClintock, N. (2014) 'Radical, reformist, and garden-variety neoliberal: coming to terms with urban agriculture's contradictions', Local Environment 19(2): 147-171.

McNay, L. (2014) The Misguided Search for the Political: Social Weightlessness in Radical Democratic Theory. Cambridge: Polity Press

Meyer, J. and Kersten, J. (eds.) (2016) The Greening of Everyday Life. Oxford: Oxford University Press. de Moor, J. (2017) 'Lifestyle politics and the concept of political participation', Acta Politica, 52(2): 179197.

de Moor, J. (2018) 'Shift or synergy? Comparing practice-based and contentious environmental activism between two British cities'. Sustainable Materialism workshop, University of Edinburgh, July 12, 2018.

North, P. (2010) 'Eco-localisation as a progressive response to peak oil and climate change: a sympathetic critique'. Geoforum 41: 585-594.

Peck, J. and Ward, K. (2002) 'Placing Manchester' in J. Peck and K. Ward (eds.) City of Revolution:

Restructuring Manchester, 1-17. Manchester: University of Manchester Press.

Pink, S. (2012) Situating Everyday Life: Practices and Places. London: Sage.

Schlosberg, D. (2018) 'Sustainable materialism, environmentalism and everyday practice'. Sustainable Materialism workshop, University of Edinburgh, July 12, 2018.

Schlosberg. D. and Coles. R. (2016) 'The new environmentalism of everyday life: sustainability, material flows, and movements' Contemporary Political Theory 15(2):160-181.

Swyngedouw, E. (2013) 'The non-political politics of climate change' ACME. Int. E-J. Crit. Geogr. 12 (1): 18.

Tonkiss, F. (2013) 'Austerity urbanism and the makeshift city' City 17(3):312-324.

Uitermark, J. and Nichols, W. (2014) 'From politicization to policing: the rise and decline of new social movements in Amsterdam and Paris' Antipode 46(4):970-991. 
University of Manchester (2018) 'Manchester Universities' “Give it Don't Bin it” campaign is an award winner' Press Release. Online at https://www.manchester.ac.uk/discover/news/manchesteruniversities-give-it-dont-bin-it-campaign-is-an-award-winner/ (accessed 12-09-18).

Williams, A., Goodwin, M. and Cloke, P. (2014) 'Neoliberalism, Big Society, and progressive localism' Environment and Planning A 46:2798-2815.

Wilson, J. and Swyngedouw, E. (eds.) (2014) The Post-political and its Discontents Edinburgh: Edinburgh University Press.

Wright, E. O. (2010) Envisioning Real Utopias. London: Verso. 